\title{
ZASTOSOWANIE METOD GIS DO OCENY STOPNIA PRESJI INWESTYCYJNEJ W ZAKRESIE DZIAŁALNOŚCI DEWELOPERSKIEJ NA PRZYKŁADZIE STREFY PODMIEJSKIEJ KRAKOWA
}

\begin{abstract}
Artykuł prezentuje możliwości zastosowania metod geomatycznych w kompleksowej ocenie zjawiska presji inwestycyjnej na obszarach strefy podmiejskiej Krakowa. Strefa podmiejska jest to teren chętnie wybierany przez deweloperów oferujących mieszkania ludności pracującej w Krakowie. Tereny wybierane przez deweloperów podlegają w szczególnie widoczny sposób szybkiemu procesowi suburbanizacji. Obszary użytkowane rolniczo zmieniają swój charakter na miejski. W zabudowę rolniczą wpisują się osiedla deweloperskie, które są powodem dysharmonii w krajobrazie wiejskim prowadząc nierzadko do konfliktów przestrzennych. Poruszone zagadnienie wpisuje się w zakres identyfikowania obszarów problemowych w oparciu o dokumenty planistyczne tworzone w procesie planowania miejscowego. Obszar problemowy jest rozumiany jako „obszar szczególnego zjawiska z zakresu gospodarki przestrzennej lub występowania konfliktów przestrzennych” [Ustawa 2003]. Analizy bazują na wybranych współczynnikach służącymi do badania stanu zagospodarowania przestrzennego, w tym miarach koncentracji zbioru punktów na płaszczyźnie. W tym celu zastosowano podstawowe techniki geoprocessingu. Analizy opracowano w programie QGIS.
\end{abstract}

Słowa kluczowe: przestrzeń planistyczna, obszary podmiejskie, monokultura funkcjonalna, intensywność zabudowy, współczynnik koncentracji zabudowy

\footnotetext{
${ }^{1}$ Autor do korespondencji/corresponding autor: Barbara Prus, Uniwersytet Rolniczy w Krakowie, Wydział Inżynierii Środowiska i Geodezji, Katedra Gospodarki Przestrzennej i Architektury Krajobrazu, ul. Balicka 253c, 30-149 Kraków, b.prus@ur.krakow.pl

${ }^{2}$ Tomasz Salata, Uniwersytet Rolniczy w Krakowie, ul. Balicka 253c, tel. 146624017 , tomasz.salata@ur.krakow.pl

${ }^{3}$ Krzysztof Gawroński, Uniwersytet Rolniczy w Krakowie, ul. Balicka 253c, 146624017 , krzysztof.gawronski@ur.krakow.pl
} 


\section{Wstęp}

Planowanie miejscowe realizowane na poziomie gminy warunkuje rozwój jednostek osadniczych zgodny z zasadą zrównoważonego rozwoju definiowanego jako racjonalne wykorzystanie przestrzeni i środowiska jako dóbr ograniczonych [Domański 2013]. Ograniczoność przestrzeni jest powodem, że grunty, szczególnie te zlokalizowane w bliskim sąsiedztwie prężnie rozwijających się ośrodków miejskich podlegają silnej presji i konkurencji [Domański 2013]. W związku z ograniczonością przestrzeni już od kilkunastu lat głoszone są postulaty oszczędnego nią gospodarowania [Szulczewska 2000, Matysiak 2004, Poniży 2009]. Przestrzeń bywa bowiem także rozpatrywana w kategoriach ekonomicznych, jako dobro posiadające określoną wartość, generujące przychód i dochód oraz wymagające ponoszenia kosztów, w tym np. z tytułu ochrony środowiska [Wańkowicz 2010]. Działalność człowieka wymaga uwzględnienia zapotrzebowania na przestrzeń indywidualną, ale także kulturową, publiczną i społeczną. Obszary spełniają funkcję miejsca zamieszkania i odpoczynku, a także miejsca pracy.

Zadaniem planowania przestrzennego, w tym w głównej mierze planowania miejscowego, jest przeznaczanie terenów na określone cele wraz z wyznaczaniem parametrów zagospodarowania i zabudowy [Ustawa 2003], określanych w miejscowym planie zagospodarowania przestrzennego [Kwaśniak 2009], a w przypadku jego braku w studium uwarunkowań i kierunków zagospodarowania przestrzennego [Ustawa 2003]. W planach miejscowych określa się m.in. kierunki rozwoju gminy, w tym dopuszczalny zakres zmian w strukturze przestrzennej gminy i w przeznaczeniu terenów, a także ograniczenia dotyczące tych zmian. $\mathrm{Z}$ dokumentów planistycznych wynikają minimalne i maksymalne parametry oraz wskaźniki urbanistyczne do zagospodarowania i użytkowania terenu z uwzględnieniem rozwoju zrównoważonego oraz ładu przestrzennego.

Ostatnie dziesięciolecia przyniosły m.in. zmianę sposobu użytkowania ziemi na obszarach wiejskich, ale także przeobrażenia gospodarcze, społeczne, kulturowe i architektoniczne [Sokołowski 1999]. W sposób niekontrolowany i chaotyczny powiększa się obszar stref podmiejskich [Poniży 2009, Springer 2013]. Zjawisko ekspansji infrastruktury miejskiej na obszary wiejskie w Polsce obserwowano już na początku lat osiemdziesiątych, definiując je jako transurbacja [Bartkowski 1981]. W kolejnym dziesięcioleciu jako transurbacja demograficzno-deglomeracyjna zdefiniowano zjawisko ,ucieczki” mieszkańców miast na tereny podmiejskie. Najczęściej jednak w literaturze przedmiotu proces zachodzący na obszarach miast i w bliskim ich sąsiedztwie jest nazywany suburbanizacją, natomiast $\mathrm{w}$ języku angielskim jest określany jako urban sprawl, co można przetłumaczyć jako rozlewanie się miast [Parysek 2008]. Ze zjawiskiem suburbanizacji ściśle związana jest tzw. presja urbanizacyjna (inwestycyjna), zwana także ekspansją miast, polegająca na zajmowaniu coraz większych powierzchni rolniczej przestrzeni produkcyjnej pod zabudowę mieszkaniową oraz 
wielkopowierzchniową (hale, magazyny). Zmianie ulega struktura przestrzenna wsi, a przeobrażenia obejmują formy rolniczego użytkowania terenu wraz ze wszystkimi elementami towarzyszącymi [Sokołowski 1999, Głaz 2006]. Skutki rozlewania się miast na strefy podmiejskie są z ekonomicznego punktu widzenia niekorzystne, co zauważono już w latach sześćdziesiątych XX wieku w Europie Zachodniej. Także i w Polsce są to zjawiska niepożądane ze względu m.in. na nieracjonalne wykorzystanie terenu, zmniejszenie powierzchni wykorzystywanych rolniczo i tzw. terenów otwartych, zwiększenie kosztów budowy sieci infrastruktury technicznej, czy wzrost natężenia ruchu drogowego [Kamiński 1995, Springer 2013]. Jednocześnie rozwój przestrzeni podmiejskiej realizowany jest kosztem przyrodniczego i rolniczego otoczenia [Czochański 2007]. Biorąc pod uwagę indywidualny interes mieszkańców, posiadanie domu na terenie podmiejskim umożliwia poprawę warunków mieszkaniowych, rekreację w przyjaznym środowisku, czy wyższy stopień prywatności [Parysek 2008].

Tabela 1. Skutki presji inwestycyjnej na tereny rolnicze

Table 1. The effects of investment pressure on agricultural land

\begin{tabular}{|l|l|}
\hline $\begin{array}{l}\text { Zagospodarowanie } \\
\text { i środowisko }\end{array}$ & $\begin{array}{l}\text { - niekontrolowane zmiany w zagospodarowaniu przestrzennym } \\
\text { - negatywne zmiany w krajobrazie i środowisku } \\
\text { - niska efektywność użytkowania przestrzennego (np. koszty infra- } \\
\text { struktury) }\end{array}$ \\
\hline Demografia & $\begin{array}{l}\text { - deglomeracja miast } \\
\text { - pogtębienie negatywnych zjawisk demograficznych } \\
\text { - przeksztatcenie struktury przestrzeni (np. koszty infrastruktury) }\end{array}$ \\
\hline Transport & $\begin{array}{l}\text { - wzrost liczby przejazdów (obciążenie sieci i konieczność rozwoju } \\
\text { infrastruktury transportowej) } \\
\text { - spadek liczby mieszkańców w zasięu obstugi wysokowydajnych } \\
\text { systemów transportowych } \\
\text { - przeniesienie potrzeb transportowych na prywatne środki trans- } \\
\text { portu i systemy nieprzyjazne środowisku }\end{array}$ \\
\hline Gospodarka & $\begin{array}{l}\text { - zmniejszenie zaplecza żywicielskiego } \\
\text { - zaburzenie struktury ustug (niedobór infrastruktury spotecznej) }\end{array}$ \\
\hline
\end{tabular}

Źródło: opracowano na podstawie [Kmieć, Kmieć 2014]

W Polsce sukcesywnie wzrasta powierzchnia gruntów wyłączanych z produkcji rolnej [Fogel 2010, Prus 2012]. Na terenach przylegających do dużych miast znaczny wpływ na odrolnienia posiada działalność deweloperska. Nowe osiedla mieszkaniowe powstające w bliskim sąsiedztwie miast nie zachowują tożsamości regionu, w który się wpisują, lecz prowadzą do intensywnej zabudowy przestrzeni. $Z$ drugiej strony przedsięwzięcia dewelopera mają na celu skupienie na niewielkim obszarze dużej liczby budynków oraz infrastruktury technicznej co zapobiega niekorzystnemu zjawisku rozpraszania zabudowy.

Analizy stanu zagospodarowania przestrzeni opierają się na przetwarzaniu dużej liczby danych przestrzennych. Do badań przyjmuje się geograficzne sys- 
temy informacji przestrzennej, posiadające szerokie spektrum zastosowań [Gotlib i in. 2007, Szymańska 2009, Kuraś 2007, Leszczyńska 2010]. Analizy przestrzenne, polegające na przekształcaniu zbiorów danych, bazują na wielotematycznych zapytaniach, agregacji danych, sumowaniu i mnożeniu warstw. Umożliwiają dowolne przekształcenia zbiorów danych przestrzennych oraz ich wzajemną konfrontację. Celem artykułu jest prezentacja możliwość zastosowania metod geomatycznych do oceny stanu zagospodarowania przestrzennego oraz stopnia presji urbanistycznej (inwestycyjnej), na obszarze inwestycji deweloperskiej.

\subsection{Obszar badań oraz metoda badawcza}

Badania przeprowadzono na terenie gminy Michałowice, od strony północnej przylegającej do gminy miejskiej Kraków.

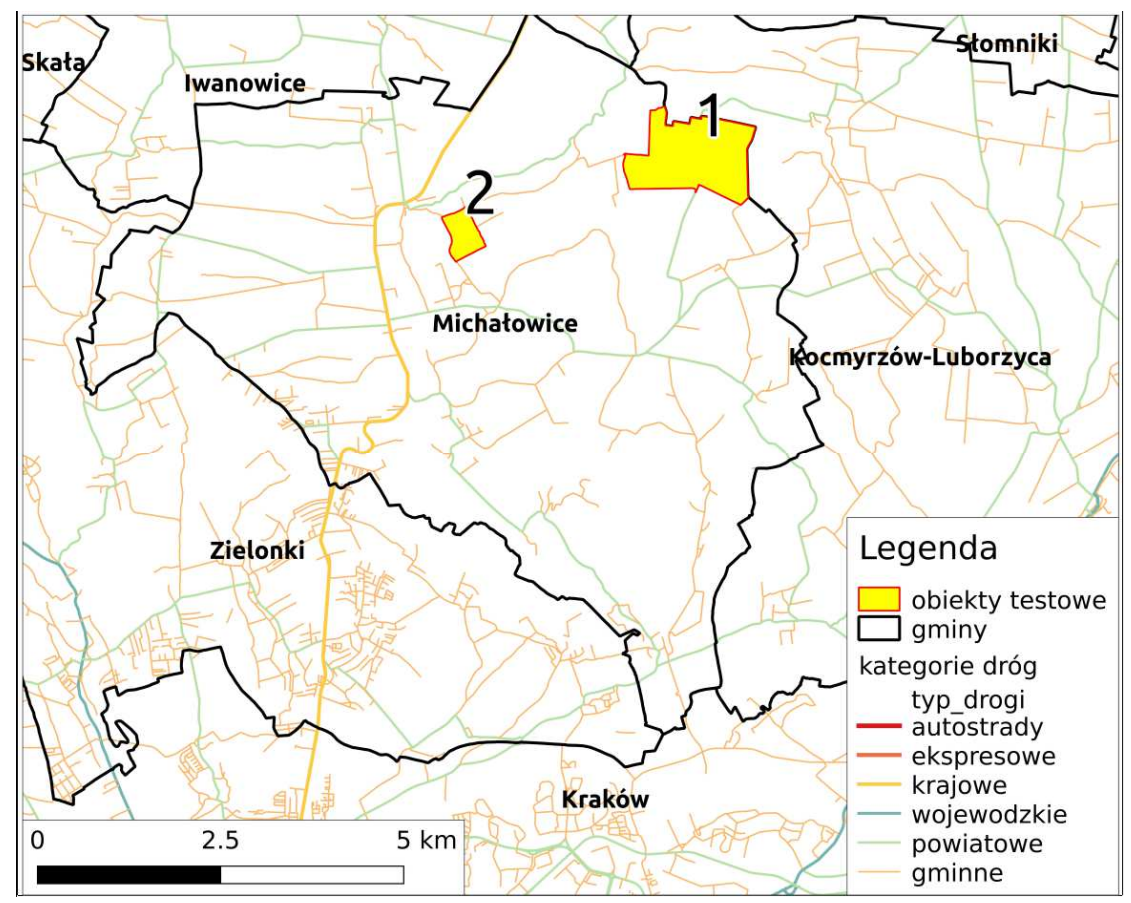

Rys. 1. Lokalizacja obszarów badań w odniesieniu do Krakowa

Fig. 1. Research areas in relation to Krakow

Jest to teren pagórkowato ukształtowany, co niejednokrotnie podnosi walory widokowe. Migracja mieszkańców Krakowa do gmin podkrakowskich jest zjawiskiem zauważalnym od kilkunastu lat. Jednak najbardziej widoczne zmiany dotyczą bezpośredniego sąsiedztwa Krakowa. Jako bazę badawczą niniejszego 
opracowania przyjęto dwa modelowe obiekty, przyjmując przy ich doborze założenie o porównywalnej liczebności budynków w obu obiektach, stąd posiadają one różną powierzchnię, kształt, czy układ sieci komunikacyjnej. Oceny dokonano w oparciu o porównanie dwóch obiektów badawczych.

Obiekt 1 - obejmuje obszar 150,8750 ha; charakteryzuje się tradycyjnymi formami zabudowy w typie ulicówki, jest zlokalizowany w odległości ok. $10 \mathrm{~km}$ od Krakowa oraz ok. $5 \mathrm{~km}$ od drogi krajowej (ekspresowej). Obiekt 2 to teren o powierzchni jedynie 24,8864 ha, niemal w całości znajdujący się w posiadaniu developera, został zaplanowany jako zwarte osiedle mieszkaniowe. Tu zabudowa zarówno ta już zrealizowana (przedstawiona na rys.2. kolorem czarnym) oraz zabudowa będąca $w$ trakcie realizacji lub na etapie planowanym (oznaczona na ryc.2. kolorem szarym) bardzo różni się od tradycyjnej wiejskiej zabudowy zagrodowej. Niemniej jednak sposób ułożenia i geometrii elementów składowych obiektu 2 w maksymalny sposób wykorzystuje powierzchnię, w odróżnieniu od zabudowy rozproszonej. Przedstawia to rysunek 2.
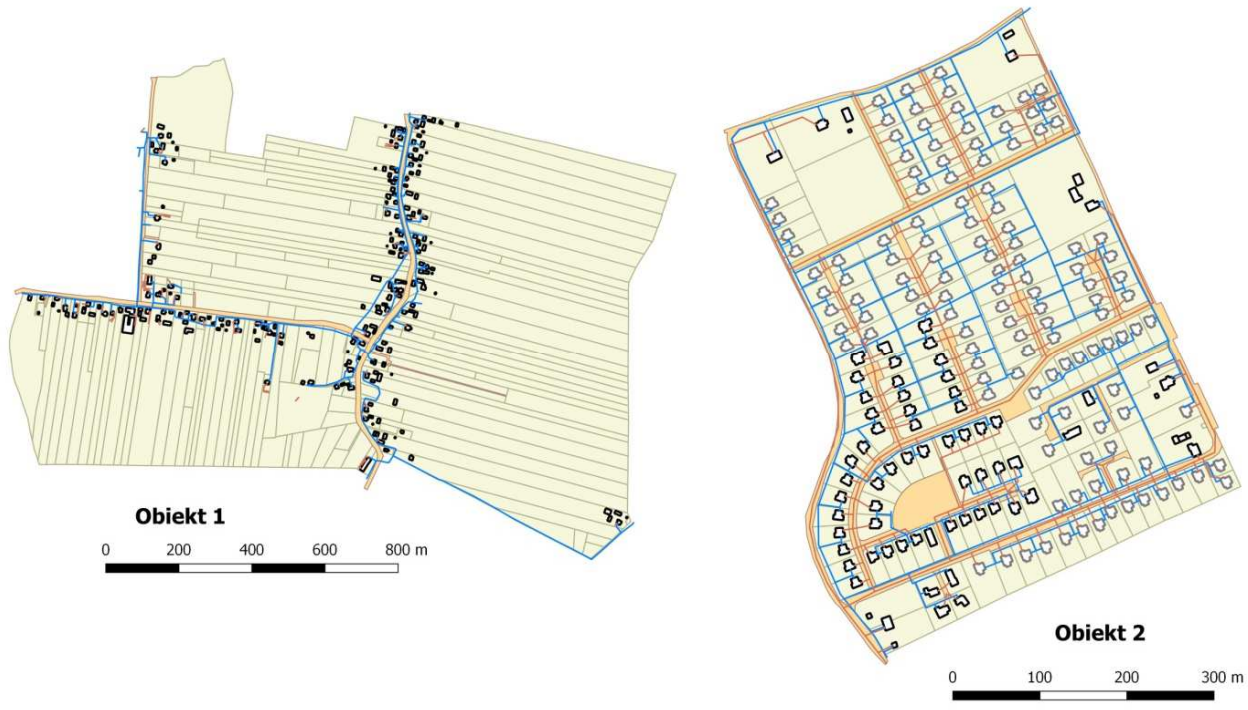

Rys.2. Obszary testowe

Fig.2. Case studies

Prace analityczne przygotowano tworząc bazę danych przestrzennych w formacie SQLite/SpatiaLite, używając do jej obsługi Wolne Oprogramowanie SpatiaLite_GUI oraz QGIS. Każda tabela posiada przypisane odwzorowanie na bazie systemu EPSG (skr. European Petroleum Survey Group) o kodzie EPSG:3120, co odpowiada PUWG " 65 ” strefa 1 . Tabele w bazie: budynki, działki i uzbrojenie.

Budowa tabel z danymi jest następująca:

- budynki, reprezentują kontur budynków, zastosowany został klusz główny unikatowy, reprezentowany przez wartości całkowite, autonumerowane; iden- 
tyfikator budynku zgodnie z ustawą Prawo geodezyjne i Kartograficzne [Ustawa 1989], 'nazwa' i 'funkcjauzy', czyli format asocjacyjny i dyskretny zapisu funkcji użytkowej budynku, status - informacja o istnieniu budynku, obiekt - informacja, do którego obiektu należy budynek (Obiekt 1 to tradycyjny układ zabudowy, Obiekt 2 to przestrzeń zagospodarowana przez developera). Ostatnim atrybutem jest powierzchnia obliczona z mapy (funkcje \$area, Area(Geometry) ). Zapis SQL tabeli 'budynki' przedstawia się następująco:

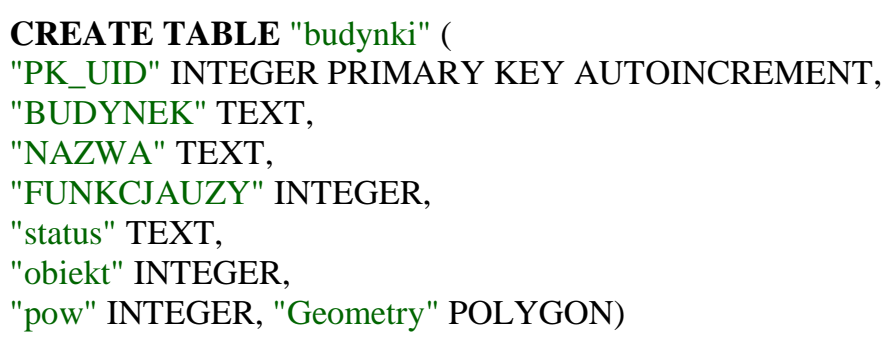

- działki to tabela reprezentująca granice działek zgrupowanych w nieruchomości (zaliczonych do osobnej jednostki rejestrowej w rozumieniu przepisów rozporząadzenia w sprawie Ewidencji Gruntów i Budynków [Rozporząadzenie 2013]. Podobnie jak w tabeli budynków założony został klucz główny oraz atrybuty: 'działkaewi' i 'nazwa' jako identyfikatory działki wg systemu TERYT2 [Ustawa 1989], 'nr_obiektu' - informacja, do którego obiektu testowego należy budynek, 'typ_nieruch' - klasyfikacja typu obiektu wg słownika na: nieruchomość gruntową i drogę. Ponadto powierzchnia działki obliczona z mapy w hektarach jako działanie funkcji \$area, Area(Geometry). Poniżej zapis SQL:

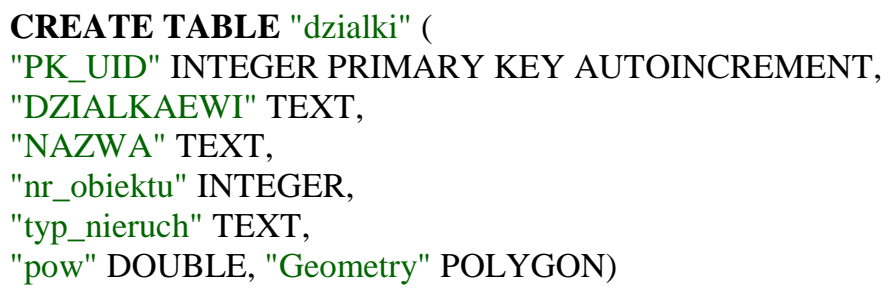

- tabela uzbrojenia terenu reprezentuje jedynie liniowe podziemne techniczne zagospodarowanie terenu. $\mathrm{Z}$ uwagi na charakter badań dane zostały ograniczone do linii wodnych i kanalizacyjnych (w zakresie merytorycznym gminy, podobnie jak wykonanie MPZP). Oprócz klucza głównego, niezbędne atrybuty to: typ przewodu, jego średnica wyrażana w milimetrach, przynależność przewodu do obiektu testowego oraz obliczona długość przewodu z mapy za pomocą funkcji \$length, Length(Geometry). Zapis SQL tabeli 'uzbrojenie' przedstawia się następująco:

CREATE TABLE "uzbrojenie" ( "PK_UID" INTEGER PRIMARY KEY AUTOINCREMENT, "typ" TEXT, 


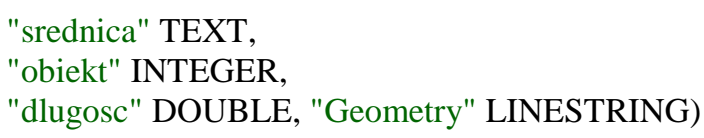

Liczbę działek, sumę powierzchni i inne podstawowe parametry statystyczne dla nieruchomości uzyskano stosując zapytanie SQL o następującej składni, oraz z podziałem na typ nieruchomości: dla działek stanowiących nieruchomości do zabudowy lub zabudowane i działki drogowe.

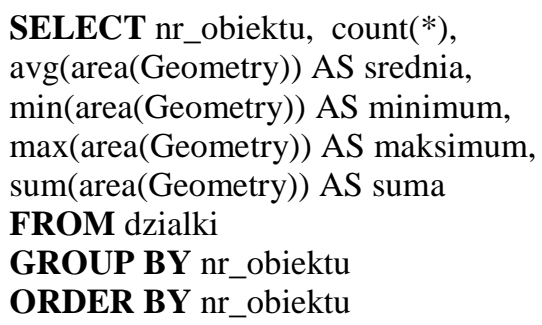

SELECT nr_obiektu,typ_nieruch, count(*), $\operatorname{avg}(\operatorname{area}($ Geometry)) AS srednia, min(area(Geometry)) AS minimum, max(area(Geometry)) AS maksimum, sum(area(Geometry)) AS suma FROM dzialki_single GROUP BY nr_obiektu, typ_nieruch ORDER BY nr_obiektu

Strukturę powierzchni zabudowy, liczebność budynków z podziałem na obiekty testowe otrzymano stosując zapytanie SQL odwołujące się do tabeli budynków:

SELECT obiekt,NAZWA as funkcja_uzytkowa, count(*), sum(area(Geometry)) AS suma_powierzchni FROM budynki

GROUP BY obiekt, NAZWA

ORDER BY obiekt ASC, NAZWA ASC

Długość sieci wodociągowej obliczono stosując podobne zapytanie SQL. Grupowanie zostało określone kaskadowo dla obiektu testowego i średnicy. Typ uzbrojenia nie był wykorzystywany z uwagi na fakt, że można było porównać jedynie sieć wodociągową ze względu na uzbrojenie 100\% obiektów (budynków mieszkalnych) w obu polach testowych. System kanalizacyjny był rozwinięty jedynie w obiekcie 2 . W obiekcie 1 występuje jedynie odprowadzenie ścieków do zbiorników przydomowych.

SELECT obiekt,typ, count(*), sum(length(Geometry)) AS suma_długości

FROM uzbrojenie

GROUP BY obiekt, typ

ORDER BY obiekt ASC, typ ASC 
Badania zmian zagospodarowania przestrzennego wykonano korzystając z metody kartometrycznej analizy porównawczej. Do badań użyto następujące materiały źródłowe:

- mapę zasadniczą w formacie GML według stanu z kwietnia 2015 r.,

- mapę ewidencji gruntów i budynków w formacie SWDE, stan z kwietnia $2015 \mathrm{r}$.

Porównanie dotyczyło różnic pomiędzy sposobem zagospodarowania przestrzeni, co jest wynikiem działania presji inwestycyjnej. Wyrażać ona może się nie tylko w dążeniu do mieszkaniowego charakteru terenu lecz również w geometrycznym sposobie zainwestowania terenu. Model kompaktowy stosowany przez rozwiązania developerskie naprzeciw ulicowej, chaotycznej i przypadkowej zabudowy tradycyjnej. Różnice są widoczne na poniższej rycinie (Rys. 3).

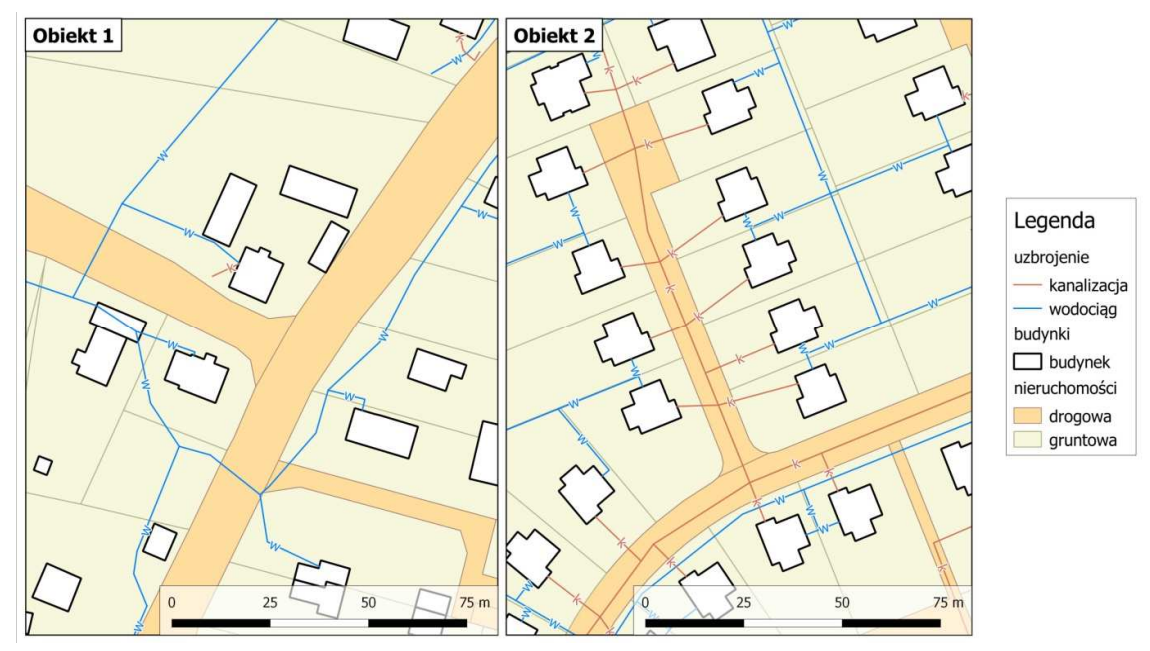

Rys. 3. Sposób zagospodarowania przestrzeni w obiektach testowych

Fig. 3. Space development in case studies

Porównanie przestrzennego rozmieszczenia zabudowy w obiektach badawczych pozwala na stwierdzenie, iż obiekt 1 skupia zabudowę rolnicza (zagrodową). Na rys. 3. widocznym jest, że obiekt posiada chaotyczny układ działek oraz niepełne wyposażenie $\mathrm{w}$ infrastrukturę wodno-kanalizacyjną. Obiekt 2 posiada zabudowę zwartą, natomiast działki posiadają regularny kształt oraz pełne wyposażenie w przyłącza wodno-kanalizacyjne.

\section{Wyniki badań}

Na badanym obszarze można od kilkunastu lat zauważyć systematyczny wzrost powierzchni zabudowanych kosztem rolniczej przestrzeni produkcyjnej. 
Sukcesywnie wzrasta powierzchnia przeznaczana w miejscowym planie zagospodarowania przestrzennego pod zabudowę mieszkaniową. Porównując ze sobą dwa analizowane obiekty badawcze można zauważyć, że pierwszy stanowi typowy przykład zabudowy tzw. ulicówki, tworzonej przez stulecia poprzez sukcesywną zabudowę przestrzeni wokół głównych dróg. Drugi to przykład zaprojektowanej jako integralna całość rzędówki, z wyznaczonymi trasami komunikacyjnymi oraz zwartą zabudową.

Tabela 2. Parametry obiektów badawczych pod kątem wielkości działek oraz rodzaju zabudowy

Table 2. Size plots and type of building parameters in case studies

\begin{tabular}{|c|c|c|c|c|c|}
\hline Obiekty & $\begin{array}{c}\text { Średnia pow. } \\
\text { dziatki [ha] }\end{array}$ & $\begin{array}{c}\text { Liczba } \\
\text { dziatek }\end{array}$ & $\begin{array}{c}\text { Max pow. } \\
\text { dziatki [ha] }\end{array}$ & $\begin{array}{c}\text { Min pow. } \\
\text { dziatki } \\
{[\text { ha] }}\end{array}$ & $\begin{array}{c}\text { Suma } \\
\text { pow. }[\text { ha] }\end{array}$ \\
\hline $\mathbf{1}$ & 0,8155 & 185 & 4,4243 & 0,0039 & 150,8750 \\
\hline $\mathbf{2}$ & 0,1179 & 211 & 0,9113 & 0,0025 & 24,8864 \\
\hline
\end{tabular}

Jeszcze przed 2000 rokiem na badanym terenie dominowała zabudowa o charakterze wiejskim, $\mathrm{z}$ zabudową zagrodową, podwórzem $\mathrm{z}$ budynkiem mieszkalnym oraz zabudowaniami gospodarczymi. Po 2000 roku zaczęto lokalizować wolnostojące domy jednorodzinne na działkach o kilkunasto lub kilku arowej powierzchni. Szczególnym przypadkiem zabudowy na analizowanym obszarze strefy podmiejskiej Krakowa są osiedla deweloperskie różniące się od „starej wsi” układem i wielkością działek, formami zabudowy, stanem infrastruktury technicznej, czy wreszcie parametrami urbanistycznymi. Inwestor grunt pod lokalizację osiedla mieszkaniowego pozyskał od mieszkańców wsi rolników. Stąd w regularnym układzie zabudowy szeregowej pojawiają się przypadki dawnej zabudowy zagrodowej.

Na obszarach wiejskich Polski południowej po I wojnie światowej współczynnik gęstości zabudowy wynosił średnio 14-17 budynków na $\mathrm{km}^{2}$. Odpowiednio współczynnik liczby budynków przypadającej na liczbę nieruchomości znajdował się w przedziale 1,00-1,03 [Angiel 2009]. Dokonując analizy parametrów obiektów badawczych (Tabela 2.) można stwierdzić, że dla obiektu 1 współczynnik gęstości zabudowy wynosi 152,44 budynki na $\mathrm{km}^{2}$, natomiast na obiekcie 2 aż 807,670 km². Współczynnik liczby budynków przypadających na liczbę nieruchomości dla obiektu 1 wynosi 1,24, natomiast dla obiektu $2-0,95$. Oznacza to, że na obiekcie 1 średnio każda działka jest zabudowana więcej niż jednym budynkiem, natomiast na obiekcie 2 pozostają działki niezabudowane (np. drogi). Obliczenia wykazały również różnice pomiędzy obiektami badawczymi zarówno w średniej powierzchni działki (która dla obiektu 1 jest ośmiokrotnie wyższa niż dla obiektu 2), jak również w powierzchni minimalnej oraz maksymalnej działek gruntowych. W kompleksie zabudowy developerskiej maksymalna powierzchnia działki wynosi niespełna 10 arów, zaś minimalna $25 \mathrm{~m}^{2}$. W przypadku obiektu zlokalizowanego na ,starej wsi” maksymalna po- 
wierzchnia działki dochodzi do 4 ha 42 arów, natomiast minimalna liczy $39 \mathrm{~m}^{2}$. Widoczne są zatem duże rozbieżności w geometrii działek.

Tabela 3. Liczebność i struktura budynków w obiektach testowych

Table 3. The number and structure of buildings in test facilities

\begin{tabular}{|c|c|c|c|c|}
\hline \multirow{3}{*}{ Budynki } & funkcja budynku & liczba & $\begin{array}{c}\text { suma po- } \\
\text { wierzchni }\left[\mathrm{m}^{2}\right]\end{array}$ & $\begin{array}{c}\text { udziat funkcji } w \\
\text { zbiorach testowych } \\
{[\%]}\end{array}$ \\
\hline \multirow{4}{*}{ obiekt 1 } & gospodarczy & 126 & 10394 & 54,8 \\
\cline { 2 - 5 } & mieszkalny & 87 & 9991 & 37,8 \\
\cline { 2 - 5 } & nieokreślony & 17 & 2391 & 7,4 \\
\cline { 2 - 5 } & suma & $\mathbf{2 3 0}$ & $\mathbf{2 2 7 7 6}$ & $\mathbf{1 0 0}$ \\
\hline \multirow{3}{*}{ obiekt 2 } & gospodarczy & 8 & 559 & 4,0 \\
\cline { 2 - 5 } & handlowy & 1 & 153 & 0,5 \\
\cline { 2 - 5 } & mieszkalny & 189 & 22820 & 94,0 \\
\cline { 2 - 5 } & nieokreślony & 3 & 146 & 1,5 \\
\cline { 2 - 5 } & suma & $\mathbf{2 0 1}$ & $\mathbf{2 3 6 7 8}$ & $\mathbf{1 0 0}$ \\
\hline
\end{tabular}

Presja urbanizacyjna (inwestycyjna) na przedstawionych obiektach przejawiała się zasadniczo we wzroście powierzchni zabudowanej. Bardziej intensywna zmiana użytkowania terenu następuje na obiekcie nr 2 - stanowiącym zwarte, zaplanowane osiedle mieszkaniowe, co wyraża się m.in. wyższym współczynnikiem intensywności zabudowy, w tym wyższą liczbą budynków przypadających na jednostkę powierzchni. Na analizowanym obszarze widoczne są zarówno zmiany przestrzenne jak i zmiana charakteru zabudowy.

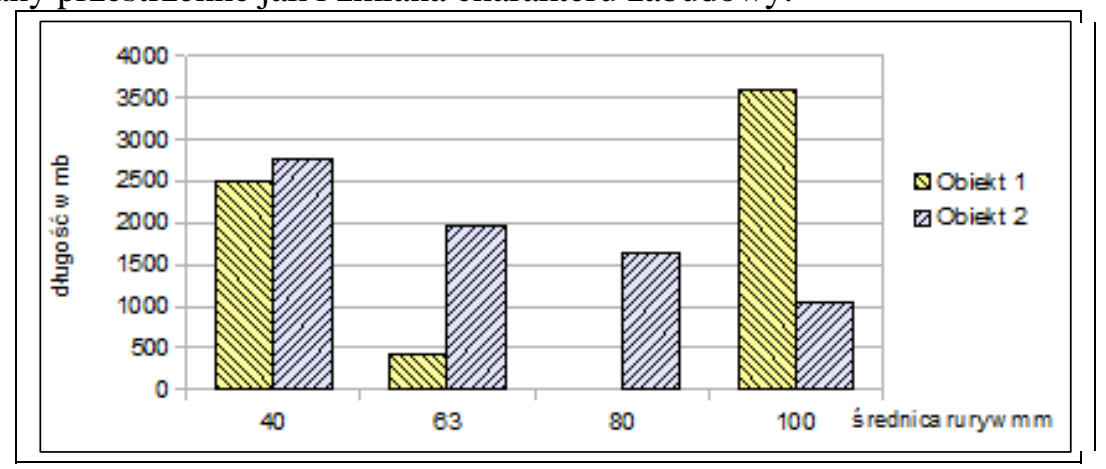

Rys. 4. Struktura długości sieci wodnej według średnic rur

Fig. 4. The length of the water supply network and its dimensions

W pierwszym analizowanym obiekcie niespełna 38\% zabudowy stanowiły budynki o funkcji mieszkaniowej, w obiekcie drugim jednorodzinna zabudowa mieszkaniowa stanowi $94 \%$ wszystkich budynków. Co więcej niespełna 54\% budynków w obiekcie 1 posiada funkcję ,,budynek gospodarczy”. 
Podobnie z udziałem długości sieci wodociągowej. W układzie zabudowy tradycyjnej widać wyraźnie bezładną trasę linii wodociągowych, główne odcinki są prowadzone rurami o znacznej średnicy, z której wprost jest wyprowadzane przyłącze domowe. To duża dysproporcja w systemie sieci rozdzielczej. W obiekcie 2 można zaobserwować lepiej zaprojektowany układ sieci rozdzielczej oraz stopniową redukcję średnic orurowania - przedstawia to rys. 4. Dla obiektu nr 1 powierzchnia wszystkich dróg to 3,0704 ha, co stanowi 2,0 \% powierzchni ogółem. W obiekcie nr 2 powierzchnia dróg to 3,6621 ha i odpowiada $14,7 \%$. W układzie komunikacyjnym obiektu 2 można zaobserwować przekomunikowanie, które dotyczy 33 nieruchomości. Posiadają one dostęp do drogi z dwóch stron - stanowi to $16,5 \%$ wszystkich nieruchomości. W obiekcie 1 przekomunikowanie dotyczy 8 nieruchomości i jest to 4,3\%. Przyczyn należy szukać w topografii terenu. Różnice w rozliczeniu długości i powierzchni dróg w obiektach testowych przedstawia tabela 4 .

Tabela 4. Wartości długości i powierzchni dróg w obiektach testowych

Table 4. Length and surface of roads in case studies

\begin{tabular}{|c|c|c|c|c|}
\hline obiekt & $\begin{array}{c}\text { liczba odcinków } \\
\text { dróg }\end{array}$ & $\begin{array}{c}\text { pow dróg } \\
\text { /ha/ }\end{array}$ & $\begin{array}{c}\text { ha // km } \\
\text { dróg/dziatkę }\end{array}$ & $\begin{array}{c}\text { ha // km } \\
\text { dróg / budynek }\end{array}$ \\
\hline 1 & 10 & 3,0704 & $0,0156 / / 0,0184$ & $0,0353 / / 0,0392$ \\
\hline 2 & 18 & 3,6621 & $0,0173 / / 0,0193$ & $0,0194 / / 0,0215$ \\
\hline
\end{tabular}

Wyraźną dysproporcję można dostrzec badając wskaźnik długości dogi przypadającej na nieruchomość (w tym przypadku liczba nieruchomości w obiektach testowych odpowiada liczbie budynków mieszkalnych), gdzie wartość współczynnika dla obiektu 2 (215 mb drogi) wynosi 54,8\% wartości obiektu 1 (392 mb drogi).

\section{Podsumowanie i wnioski}

Modelowanie danych przestrzennych pozwala na przetwarzanie informacji przestrzennej o charakterze wielokryterialnym, a analizy umożliwiają badanie relacji przestrzennych przy wykorzystaniu wektorowego sposobu zapisu. Zastosowanie metod geomatycznych usprawnia proces przetwarzania danych i umożliwia otrzymanie wyników badań na dowolnym obszarze.

Przeprowadzone analizy wykazały, że presja inwestycyjna jest powodem zmian funkcji badanych terenów podmiejskich z rolniczej na mieszkaniową. Skutkiem zmian jest powstawanie zabudowy odbiegającej od kulturowej tożsamości regionu. Na badanym obszarze zauważono zmiany suburbanizacyjne, w tym powstawanie terenów mieszkaniowych w obrębie dawnych użytków rolnych, stanowiących zaplecze rolnicze Krakowa. 
Sieć uzbrojenia terenu jest realizowana kompleksowo tylko w przypadku zabudowy developerskiej. W tradycyjnym systemie zabudowy trasy sieci są prowadzone w dowolny sposób lub nie są realizowane.

Osiedle mieszkaniowe zrealizowane przez dewelopera nie posiada powiązania z istniejącą siecią osadniczą, nie posiada także przestrzeni publicznej (integrującej). Można zatem zauważyć, że funkcja tej strefy podmiejskiej została ograniczona jedynie do roli ,sypialni miasta”. Biorąc pod uwagę fakt, że napływowi mieszkańcy terenów podmiejskich będą związani z miastem, obszary podmiejskie będą stanowiły monokulturę funkcjonalną [Dylewski 2006].

Tereny zabudowy developerskiej charakteryzuje jednolitość form działek gruntowych oraz stylu architektonicznego powstającej zabudowy. Taka jednolitość formy i kształtu jest nie możliwa do zrealizowania w przypadku różnych, indywidualnych inwestorów.

\section{Literatura}

[1] Angiel M.: Wieś tradycyjna w krajobrazie Pogórzy Karpackich. [w:] Polskie krajobrazy wiejskie dawne i współczesne. Prace Komisji Krajobrazu Kulturowego nr 12. Komisja Krajobrazu Kulturowego PTG, Sosnowiec 2009.

[2] Bartkowski T.: Transurbacje miast Wielkopolski i niektóre zagadnienia przestrzenno-planistyczne ich rozwoju oraz zastosowanie do nich niektórych metod fizjografii urbanistycznej. Wydawnictwo Naukowe UAM, Seria Geografia 22, Poznań 1981.

[3] Czochański J.: Dezintegracja przestrzenna w rozwoju obszaru metropolii trójmiejskiej. [w:] M. Kistowski, B. Korwel-Lejkowska (red.), Waloryzacja środowiska przyrodniczego w planowaniu przestrzennym. Problemy Ekologii Krajobrazu XIX, Warszawa-Gdańsk 2007, s. 195-208.

[4] Domański R.: Gospodarka przestrzenna. Podstawy teoretyczne. Wydawnictwo Naukowe PWN, Warszawa 2013.

[5] Dylewski R.: Problemy rozprzestrzeniania się miast w świetle doświadczeń krajów UE i USA. [w:] S. Kozłowski (red.), Żywiołowe rozprzestrzenianie się miast. Narastający problem aglomeracji miejskich w Polsce. KUL, PAN Komitet Człowiek i Środowisko, Białystok-Lublin-Warszawa 2006, s. 27-38.

[6] Fogel P.: Obszary problemowe rolnictwa w świetle planowania miejscowego. Studia i Raporty IUNG PIB 2010, Zeszyt 19, s.19-26.

[7] Głaz M.: Przekształcenia agrarne strefy podmiejskiej jako efekt oddziaływania miasta Wrocławia. [w:] J. Słodczyk, R. Klimek (red.), Przemiany przestrzeni miast i stref podmiejskich. Uniwersytet Opolski, Opole 2006, s. 153-166.

[8] Gotlib D., Iwaniak A., Olszewski R.: GIS. Obszary zastosowań. Wyd. PWN, Warszawa 2007.

[9] Kamiński Z.: Degradacja wartości kulturowych wsi na obrzeżach miejsko-wiejskich. [w:] Z. Kamiński (red.), Urbanizacja wsi w obrzeżach miejsko-wiejskich. Materiały konferencyjne, Katowice 1995, s. 29-40.

[10] Kmieć A., Kmieć T.: Kierunki zmian presji inwestycyjnej na tereny rolnicze województwa śląskiego. 2014. 
[11] Kuraś B.: Wykorzystanie GIS jako kompleksowego narzędzia waloryzacji środowiska przyrodniczego pod kątem planowania przestrzennego i zagospodarowania terenu. Archiwum Fotogrametrii, Kartografii i Teledetekcji, AP, Kraków 2007, Vol. 17b, s.425-435.

[12] Kwaśniak P.: Plan miejscowy w systemie zagospodarowania przestrzennego. Wyd. LexisNexis, Warszawa 2009.

[13] Leszczyńska M.: System wspomagania decyzji optymalizujących rozwój marginalnych obszarów wiejskich. Acta Sci. Pol., Geodesia et Descriptio Terrarum 9(4) 2010, s. 37-48.

[14] Matysiak J.: Człowiek a ład przestrzeni. W: T.J. Chmielewski (red.), Nowa jakość krajobrazu. Ekologia-Kultura-Technika, Komitet PAN Człowiek i Środowisko, Zeszyty Naukowe 36. Warszawa-Lublin 2004, s. 59-69.

[15] Parysek J.: Procesy suburbanizacyjne w aglomeracji poznańskiej. W: T. Kaczmarek, A. Mizgajski (red.), Powiat poznański - jakość przestrzeni i jakość życia. Bogucki Wydawnictwo Naukowe, Poznań 2008, s. 71-90.

[16] Poniży L.: Presja urbanizacyjna i jej wpływ na zmiany przestrzennej struktury użytkowania ziemi na wybranych obszarach podmiejskich Poznania. Problemy Ekologii Krajobrazu, 2008, T. XXII. 335-342.

[17] Prus B.: Kierunki zmian przeznaczenia gruntów rolnych i leśnych w Polsce. Acta Scientiarum Polonorum. Geod. Descr. Terr. 11(2), 2012, s. 27-40.

[18] Sokołowski D.: Zróżnicowanie zbioru małych miast i większych osiedli wiejskich w Polsce w ujęciu koncepcji kontinuum wiejsko-miejskiego. Wyd. UMK, Toruń 1999, s. 31.

[19] Springer F.: Wanna z kolumnadą. Wyd. Czarna. Warszawa 2013.

[20] Szulczewska B.: Koncepcja rozwoju zrównoważonego jako podstawa strategii regionalnej - uwagi metodyczne. [w]: B. Szulczewska (red.), Przyrodnicze aspekty zrównoważonego rozwoju. Człowiek i Środowisko 24/2, IGPiK, Warszawa 2000, s. $137-153$.

[21] Szymańska D.: Geografia osadnictwa. Wydawnictwo naukowe PWN, Warszawa 2009.

[22] Ustawa o planowaniu i zagospodarowaniu przestrzennym z dnia 27 marca 2003 r. [Dz.U. $2003 \mathrm{nr} 80$ poz. 717].

[23] Ustawa Prawo Geodezyjne i Kartograficzne z dnia 17 maja 1989 r. [Dz.U. 1989 nr 30 poz. 163].

[24] Rozporządzenie Ministra Administracji i Cyfryzacji z dnia 29 listopada 2013 r. zmieniające rozporządzenie w sprawie ewidencji gruntów i budynków [Dz.U. 2013 poz. 1551].

[25] Wańkowicz W.: Planowanie przestrzeni o wysokich walorach krajobrazowych, problemy ekonomiczne. Krajobraz a turystyka. Prace Komisji Krajobrazu Kulturowego Nr 14. Sosnowiec 2010. s. 352-359.

Badania zrealizowane w ramach tematu $\mathrm{nr}$ DS 3371/KGPiAK/2015 finansowanego z dotacji celowej Ministerstwa Nauki i Szkolnictwa Wyższego. 


\section{USING OF GEOMATICS METHODS FOR EVALUATING OF INVEST PRESSURE DEGREE FOR KRAKOW SUBURBAN ZONES}

\section{S u m m a r y}

This article presents the possibility of applying the geomatic methods to comprehensive assessment of the investment pressure phenomena in the Krakow suburban area. The suburban zone is the area of choice for developers offering homes for people working in Krakow. Areas chosen by the developers are subject to a particularly rapid suburbanization process. The areas used for agricultural change their character to the housing zones. The agricultural buildings are part of the estate developers, which are the cause of disharmony in rural landscapes often leading to spatial conflicts. Raised the issue is in the scope of identifying of problem areas based on planning documents created in the local planning process. The problem area is understood as an "area of particular phenomena of spatial or spatial conflicts" [Act 2003]. The study was made selected coefficients are used to measure the zoning state, including measures of concentration set points in the plane. For this purpose, the basic geoprocessing techniques were used. The analysis was developed in the QGIS and spatial databases.

Keywords: space planning, peri-urban, functional monoculture, development density, coefficient of concentration of buildings

Przestano do redakcji: $10.03 .2016 r$.

Przyjęto do druku: 1.06.2016 r.

DOI: $10.7862 /$ rb.2016.129 